\title{
Passover of Border Situations. Experience of Liturgy in Labor Camp Literature*
}

\begin{abstract}
Among many statements in 1995 concerning the celebration of traces of memory of people saved from the ravages of two totalitarian regimes, there appeared articulated in various ways - attempts to outline a broad perspective on comparing the situation of victims of the Nazi and Stalinist systems. Among them the statement of Elie Wiesel was especially interesting, included in the interview "Kiedy życie było zbrodnią." Wiesel's statement suggests the incomparability of the evil of both systems and the scale of human suffering ${ }^{2}$. When asked about the interpretation of the Holocaust he replies: "If someone tries to explain the Holocaust from the point of view of theology, then I cannot accept such an explanation." There is no response, there should be no response. "The Holocaust should remain an eternal question for mankind." ${ }^{3}$ An incomparable and eternal inquiry. Mystery and silence. This is a very characteristic approach to the mystery of extermination on the part of Jewish philosophical and theological thought. It achieves in some radical factions, the total negation of the possibility of speaking about God after Auschwitz, or even a radical negation
\end{abstract}

* STV 36(1998)1.

1 E. Wiesel, Kiedy życie było zbrodnią. Z (...) rozmawia J. B. Warman, "Gazeta Wyborcza," No. 23, 27.01.1995, 13.

2 To the question: "Was Oświęcim something unprecedented? Or is it possible to compare the Nazi system of extermination camps with, for example, Gulag?” Wiesel responds: "No. Gulag is obviously one of the greatest tragedies of our century, if only because of the number of victims. But when Stalin wanted to murder someone - a personal enemy, a political opponent, a Trotskyist - he did not, however, kill his family. He could have sent the wife of such a man to the camp, but his children were sent to an orphanage and could survive. The Holocaust was the first and only time in history, when BEING itself was considered a crime. So I think it was something unique." Ibid.

3 Ibid. 
of the legitimacy of the existence of ethics in our time $e^{4}$. Is the reality described as "theology after Auschwitz" possible at all, but also is the "theology after the Gulag" also possible? The answer to this second question can be found in the analysis of memoirs. It is not only a record of facts, but also a peculiar locus theologieus ${ }^{5}$.Amongst these types of literary events, it is worth highlighting the significant phenomenon of our passing age, which is labor camp literature ${ }^{6}$. As a position that determines our view, one should adopt the status of man, the enemy closed in a world of labor camps, in order to understand the senses of the phenomenon of man's transition from what seemed to be his definitive detention and enslavement.

\section{Border Situations as Anti-reality and an Attempt to Annihilate Man}

When talking about Stalinist labor camps and the entire process of "lagerisation" of human life (from arrest, through transit prisons, investigating prisons, deportations, labor camps, to extreme conditions of so-called "repatriation") one can use the category of "borderline situations" inspired by existentialist philosophy ${ }^{7}$. One of the fundamental existentialist theses is that existence exists in the context of multiple facts ${ }^{8}$. Such a context of existence creates an existential situation. There is a situation that is common to all people, which is associated mainly with another existence, nothingness, death, being as such, and also the Absolute Being. Some situations are an absolute limit to human adaptability and defenses, and furthermore, they are absolutely unavoidable, they

4 Cf. e.g. J. Wils, Vom Verstummen Gottes in der Moral. Reflexion auf die Umbruche der Ethik, (speech presented on 29.08.1995 in Freising during the $2^{\text {nd }}$ Congress of the European Society for Catholic Theology).

5 Cf. J. Szymik, W poszukiwaniu teologicznej głębi literatury Katowice 1994.

6 Cf. E. Czaplejewicz, Polska literatura łagrowa, Warszawa 1992.

7 Undoubtedly, attention should be paid to the vagueness of the terms "existential" and "existence," despite the high frequency of their use. Above all, these terms should not be identified with philosophical or artistic existentialism, especially one, its chosen faction. Their reality has a much deeper meaning. The philosophical aspect of the term "existential" emphasizes a certain manner of being, the attitude of the subject's involvement with all his existence in the cognitive situation.

8 These are facts such as: the potency of existence, biopsychic nature of man, subjective-self structure, past, fixed axiological attitude, things in the world, non-objective transcendence (existence of the other, nothingness, death, being as such, the Absolute). 
literally constitute "border situations"9 Jaspers lists four such situations: fight, guilt, suffering and death. Border experience, which is - according to Jaspers and other existentialists - a speculative concept, acquires a special, concrete verification in the camp conditions of the Stalinist system. Hence, in the space of the camps, accepting responsibility of a special weight, threat of death, great suffering and struggle takes place. Probably also nowhere else could the words of Jaspers sound more authentically and realistically-saturated with the reality of the drama of human being: "To experience border situations and to exist - this is one and the same." ${ }^{\prime 0}$ The labor camp is above all a specific space and time, radically reversing the relation of man to space-time. Here the location is made within the boundaries that are final and which cannot be crossed or bypassed. Such an impression, triggered from the outward perspective, by way of prisoners deported to his area, later became fixed. "We were gathered together in a small group, and then we moved towards the labor camp, we know that somewhere here, to the left, before entering the camp, there is a cemetery of ours, they are already outside the zone. Yes, only the one who dies, can go beyond its limits with impunity. But in vain, the eyes slide over the clumps of blueberries and heathers, in vain looking for some plaques, or at least any mounds. Smooth, indifferent, lying on its back, tundra - and nothing else." ${ }^{11}$ Crossing the border of the camp and, at the same time, the border of the whole of reality founded on totalitarianism seems to be impossible both in the perspective of time and space. With regard to time, only death seems to be the only way to overcome this situation, while in terms of space it is difficult even to imagine any fairly realistic project, which could have been possible to implement in such extreme conditions. Escape is actually impossible. It remains for the prisoners, therefore, to continue to live in the camp and face the fourfold extreme reality: fight,

9 Cf. H. Piszkalski, Problem sytuacji granicznych w ujęciu Karla Jaspersa, "Analecta Cracoviensia" 10 (1973), 10-102. Karl Jaspers himself describes the concept that interests us in this way: "As a 'boundary' I consider such situations, which consist, for example, in the fact that I am always involved in a certain situation, that I cannot live without a fight and without suffering, that I inevitably accept my own guilt, and that I must die. They do not transform, but only change in their manifestations; and if they are brought to our condition (Dasein), they are ultimate. We cannot reach over them; in our condition, we cannot see anything beyond them. They are like a wall that resists, which we bounce off. It is not in our power to change them, but only to illuminate them without explanation or partly to derive them from something that is different from them. They are all related to our condition." K. Jaspers, Philosophie, vol. 2, Springer 1932, 203.

10 Ibid., 204.

$11 \quad$ B. Obertyńska, W domu niewoli, Warszawa 1991, 144. 
guilt, suffering and death. This reality, full of indescribable horror and ugliness, was supposed to constitute, in the opinion of the creators and performers of the system, a peculiar "redeeming," "soteric" reality. At the core of the camp soteriology was the reality of human labor, slave labor, which in the camps, was strenuously positioned in opposition to morality. This statement requires some explanation. A characteristic feature of anti-labor in the labor camps and in exile was the strict dependence of nutritional norms on the work performed. It was this absolute dependence that made work a determined form of struggle for survival. "The work went far beyond our strength, and yet we tried to do it best, in part to avoid threats and insults from overseers and decurions, but mainly because we wanted to get as much food as possible. Because the size of our daily food portions depended entirely on the amount of work we did. The policy of the camp authorities consisted in constantly keeping us in a state of semi-hunger, and at the same time we were promised more food if we worked better. In this way, hunger forced us to work harder." ${ }^{2}$ In the end, hunger and work, existing in close coexistence and conditioning, despite their externality towards man, made him as if he were the author of self-enslavement. The work so enslaved in its structure became an instrument of the struggle. The struggle was introduced in a way at the very core of the structure of human labor, constituting the basis of human efforts, social relations, and also increasing the burden of human existence.

In this context, there was a utopian and sinister program of camp soteriology expressed in the language of indoctrination. "Behind the gate (...) we were awaited by a new and much more acute torment, this time in the form of a long speech made by a thick, red-eyed political commissar who showed off by it - in front of a crowd of prisoners staggering on their feet. (...) There was everything in this excellent oratory show. And the fact that we had the unprecedented honor of participating in the nationwide construction of a new port, which in honor of one of Lenin's greatest and most faithful fellow-workers (...) will be called Mołotowski. It was also about the creative role of work, which in the gloom of history turned a monkey into a human being and which, being an instrument of exploitation of man by man, evolved - within a communist system - as Stalin greatly put it brilliantly, into the matter of honor, in the matter of bravery... and lit up with the full splendor of humanism.( ... ) And about the trust placed in us by the Soviet party and power (...) And that our

12 J. Gliksman, Powiedz Zachodowi... in: Polacy w ZSRR 1939 - 1942, W. Czapska (ed.), Warszawa 1991, 133. 
fate rests in our hands, and that we can wash away our crimes with efficient work (...). And that on the Soviet land no one can live at the expense of others and that all of us here have to observe a hard but fair rule: whoever does not work, he does not eat."13

In this way, human work became a factor both able to save a man from death, and capable - which seemed almost impossible - to save him from the indelible guilt of crime, the guilt of being an enemy. Here, however, one has to think about who the enemy, in fact, was. Polish camp literature can provide here a whole catalog of specifications - a "spy" Czapski was considered an enemy (because of the city plan purchased in Paris), communist Broniewski was considered the enemy of the communist state, the teenage author of the memories of an "Enemy of Comrade Stalin" was also considered an enemy, the enemy was a Polish postal officer, since the land on which he worked was annexed by Soviet Russia, the enemy was Grubiński, the author of a play about Lenin, the enemy was G. Lipińska, who "kept in touch" with the Englishman Adam Smith, though he lived several centuries earlier ${ }^{14}$. This catalog would be terribly grotesque, if its consequence would not be a deportation to the Gulag and loss of life. So one can ask what was the common denominator of guilt of all these people? What exactly was the decisive criterion for being an enemy? The common denominator of the cases indicated suggests the only answer: BEING A HUMAN. Hence, it can be seen that the purpose of the main effort of the labor camp was not to annihilate nations, their culture, spiritual wealth, biological existence - although all this, carried out consistently in the Nazi concentration camp in Auschwitz, is a shocking and paralyzing perspective! This effort was directed at radical and final anthropological aberration. At definitive dehumanization. After all, in the case of these millions of cases, people subjected to the process of lagerisation, the stake was not to annihilate them. The whole complex system of interrogations, the entire series of simulated legal acts for many months was to lead to the recognition of fictitious guilt!

Its goal was to lead the MAN himself to destroy himself, by virtue of hypocrisy, by the power of self-destruction. The essence of this system was that MAN would recognize his guilt of BEING HUMAN. "The specificity of these conditions (Gulag conditions) was an attempt to narrow the entire richness

$13 \quad$ M. Kumorek, Z kresów do peczorskich lagrów, Warszawa 1990, 181.

14 Cf. J. Czapski, Na nieludzkiej ziemi, Warszawa 1990; W. Grubiński, Między młotem a sierpem, Warszawa 1900; G. Lipińska, Jeśli zapomnę o nich..., Paris 1988; I. Wasilewska, Za winy niepopelnione, Rome 1945; cf. also P. Bortkiewicz, Zachowanie wartości moralnych w sytuacjach granicznych. Studium na podstawie polskiej literatury łagrowej, Łódź 1994, 43-48. 
of human existence to a narrow frame of occasional interrogation, which resulted in attempting to force a man to accept guilt for the crime he did not commit. The man who, in the result of such interrogations, was sent to the labor camps, was to live in such a sense of guilt, in fact making a self-enslavement, and ultimately losing the sense of his own existence."15

ANTI-HUMAN in ANTI-WORLD. This is not only a problem of the de-heroization of human life, dehumanization of death and dying brought to the level of the disintegration of matter, but it is a question of the re-realization of the world and of man. Yes, unbelievable! And yet it was in this perspective that the phenomenon of saving a man in the anti-world took place.

\section{Passover with Christ as a Way out of the Anti-world}

Human life in the labor camps questioned both the fact and the value of human life. An illusory proposition was the suggestion of a constant fight with each other for one's own survival, with despair and nothingness. But even saved in such a way existence was radically and permanently threatened by death dehumanized and meaningless. In such a proposed survival model, of course, there could be no room for religion and normative moral principles. This project was, however, a suggestion that absolutely did not guarantee the survival of the Gulag prisoners. The prisoners themselves experienced this fact. Hence the necessity of an alternative solution that would provide survival not on the basis of consent obtained from ominous power, but on the principle of conscious and free (as far as possible) human action, appeared. In this place, however, the following question arises, so characteristic of the entire camp literature: "Are criteria and requirements of 'normal' ethics still valid (obligatory) in the structures of evil? Normal, i.e. universally-human, engraved on stone tablets? Answers are - as you know - very diverse, often extremely oppositional. No, says

15 P. Bortkiewicz, op. cit., 51. The effort focused on breaking humanity was disproportionate. Incommensurable, because he did not verify or falsify anything. It was already condemned to annihilation. The only thing was to make the VICTIM stand on the same side as her/his EXECUTIONER. That he/she would leave the side of being in the truth and stand on the side of hypocrisy, creating the anti-world, in which, as J. Strzelecki wrote: "boundless freedom took here the form of a boundless tyranny, freed from all higher rights over it, the supporters of total equalization of beliefs referred to this equality; brotherhood has been revealed in its most trivial potency, expressed in hatred of those who will be denied the title of brother." J. Strzelecki, Niegodność i godność człowieka w wieku XX, in: Zagadnienie godności człowieka, J. Czerkawski (ed.), Lublin 1994, 143. 
Herling-Grudziński, though at some point his voice will shake. Yes - as will respond with their own story and with their own choices Adolf Popławski and Grażyna Lipińska. In every labor camp - and in every, even the most extreme situation - you can meet people who will confirm this "yes"'16. The decisive value of human life is truth and freedom, integrally joined together. A man existing in extreme conditions possessed a high self-awareness of the drama of his situation and his own drama, his deeds "(gr. drama = act, deed). It meant that the human person exists, but at the same time, he becomes himself. As a result, a conviction appeared that human existence is dramatic in its nature, that is, still unresolved, problematic. The fundamental task that arose at that moment was to base this dynamism on Strength, Values, and perhaps above all, the Person who could be entrusted with one's exit and passage - exodus and Passover. In Christian thought this question, and at the same time the heart of human drama and its definitive meaning, is readable through the person of Jesus Christ. Therefore, it can be said that from the moment of the Incarnation event, "human drama has become the drama of God himself." ${ }^{17}$ The drama category first and foremost depicts the encounter of divine and human freedom in the history of salvation ${ }^{18}$. The area of camp reality in this context became a peculiar and absolutely unconquerable barrier for "the possibility of a paschal transformation of suffering from within"19 - Passover. Interiorized. Christianity made it possible to see the unique presence of Christ in this human drama. "Christ... through his own redeeming suffering, is present within every human suffering, and he can inside it act with the power of his Spirit of Truth, the Spirit of the Consolator." ${ }^{20}$ This signifies a salvific reality regarded as an immeasurable, unlimited blessing from God. This in turn is the essence of the liturgy, revealing theophany, manifestation of God ${ }^{21}$.

The action of the Spirit of the Paraclete (consolator) was revealed in the basic manifestation of human trust, prayer. It was an act of man, which took

16 I. Sławińska, My i Oni w polskiej literaturze lagrowej, "Ethos” 5(1992)1, 196.

17 W. Hryniewicz, Bóg ludzkiego dramatu - Bóg nadziei. Rozważania chrystologiczno-eschatologiczne, "Znak" 44(1992)2, 40.

18 Oikonomia is a theological category defining the action of God in the human home (oikos) and in the whole earth inhabited by him (oikoumene). In this action man and his personal drama of misery and confusion are involved. In this way the reality of the drama is created, that can be called "theodrama." Cf. H. Urs von Balthasar, Theodramatik, 4 vol., Einsiedeln 1972-1983.

19 W. Hryniewicz, Pascha Chrystusa w dziejach człowieka i wszechświata, Lublin 1991, 291.

20 Ibid., 290.

21 Cf. B. Nadolski, Słowo Boże i sakramenty święte, in: Katechizm Kościoła Katolickiego. Wprowadzenie, M. Rusecki, M. Pudełko (ed.), Lublin 1995, 150 f. 
place in situations of sudden and radical threat to his life ${ }^{22}$, it was also an initiation of hope in situations of a threat to existence, despair and inertia of the will. Significant is the mention of prayer, which along with singing allowed us to overcome the shock of deportation and allowed us to keep the distance from the reality of enslavement. "The mood is terrible. Everyone is silent with their heads down, and it is only this song that has made them raise their heads proudly upwards: O Lord, who are in the sky, take out a just hand, from the Vistula, Nemen, Warta, Bug, we are calling You today for the Polish roof and Polish weapons. This supplicatory song has a consoling function. It makes us believe that the Polish roof awaits us, that there is a weapon intended for our hands. The strength flowing from the national community is still within us. Poles are always closer to each other in misfortune and poverty than in normal life"23.

Finally, the prayer allowed us to experience, so far as one can say, not so much the state of religious ecstasy, but rather the discovery of the will to act and fight - the realization of signs of trust ${ }^{24}$. Camp literature includes the testimony of various prayers as such signs ${ }^{25}$. Prayers created in various circumstances of life confirm not only to the phenomenon of prayer, its universality, but also its, so to say, obligatory character. It is concisely mentioned in the memoirs of M. Byrska, who quotes her mother's recommendation: "Do not forget that God watches over you and you have to ask Him for protection." ${ }^{26}$ What is significant here is the expression "you have to" that conceals the normative element. Such interpretation is confirmed by the memories themselves, in which prayer is regarded as an act of obligation, carried out despite difficulties, obstacles or even persecutions ${ }^{27}$. The most significant act of trusting God in the conditions

22 Cf. F. Kułacz, "Charaktery mieliśmy jak zwierzęta” in: Wspomnienia Sybiraków, J. Przewłocki (ed.), Warszawa 1990, 13.

23 J. Markiewicz, “Sud'ba, bratok” in: Wspomnienia Sybiraków, vol. 4, J. Przewłocki (ed.), Warszawa 1991, $140 f$.

24 Cf. G. Lipińska, op. cit., 126.

25 See, for example, a fragment of the text of the litany prayer: “(...) In danger, in depression, in doubt, in need, in temptation, in sickness - we beg, support us, Lord! Give our daily bread to us, Lord! Give us strength of courage and perseverance, Your grace and mercy, Hope in You, Your patience, give it to us!" Nabożeństwo za Polskę. Litania Wojenna za Ojczyznę, in: Z teki, op. cit., 13 .

26 M. Byrska, Ucieczka z zesłania, Lublin 1987, 23.

27 Cf. A. Popławski, 12 lat lagru, Paris 1987, 88-89. The text of the prayer includes, among others the following words: "O God's heroes and God's martyrs, God of all suffering, tormenting in severe captivity, give us strength to survive, moral, spiritual and physical, so that we do not break down, do not succumb, do not go astray and that we always act as it should be." Ibid., 88 . 
of human existence was the Eucharistic sacrifice. In spite of extremely inconvenient, often impossible conditions, Holy Mass was held in almost every stage of the lagerisation process ${ }^{28}$. Of course, especially many records refer to holy masses held in the final period of deportations, during the departure of Poland from the territory of the Soviet Union. The celebrations of the Eucharist were then often associated with the wider pastoral ministry of the priests or field bishop J. Gawlina. He himself wrote in his notes: "The first service at the Yangtaha celebrated in the open air immediately caught my heart. The generals have always been a good example. The soldier sang with all his soul, received sermons with open heart, and received the holy sacraments. I have given the Sacrament of Confirmation to almost 5,500 soldiers within ten weeks, from the borders of Turkmenistan to the borders of China." ${ }^{29}$ This "mass" participation in the Eucharist must be discerned. It is confirmed by the priests' memoirs: "Behind the Poles, the Orthodox also queue up for the sacrament of confession." I stood up and explained to them that I was a Catholic priest that I had no right to confess Orthodox Christians. Then they with great regret, almost crying, reacted: "There's no difference, there is one God - they will also confess us..." Holy Mass in such an unholy place (Bezbożnik). It would seem a paradox, but is a reality ${ }^{30}$. A special place in the memory of priests recalling their memories of masses celebrated for the first time for a long time ${ }^{31}$ and masses celebrated on Christmas night ("Midnight Masses") ${ }^{32}$. These last ones seem to be a kind of synthesis of discovering God's presence in history and humanity and discovering the necessary character of believing in this presence. The existential context emphasized the dimension of the liturgical anamnesis understood as a revision and realization of the entire history of salvation ${ }^{33}$. "Immediately after these lofty moments, I started a Midnight Mass at the same Christmas Eve table." The whole decoration of the altar on the bunk consisted of two candles, and the only canonicals available and was a modest stole. It was without a doubt the most intense moment in our prison life. It is difficult to describe the experiences and

28 Cf. J. Hermanowicz, Chiny - Sybir - Moskwa. Wspomnienia misjonarza z lagrów sowieckich, London 1966, 160, M. Lęczycka, Zsyłka. Lata 1940-1946 w Kazachstanie, Wrocław 1989, 140-145.

29 J. Gawlina, Zamiast, VIII.

$30 \quad$ R. Grabski, Gdyby nie Opatrzność Boża... Paris 1985, 38. Bezbożnik is also the name of the village. See also the account of priest Bohatkiewicz; ibid., 96.

31 Cf. ibid., 30.

32 Cf. ibid., 96.

33 Cf. B. Nadolski, Liturgika, vol. 4, Poznań 1992, 15. 
emotions of that day. A joyful "Gloria in excelsis Deo" poured a new grace into the hearts as always, provided that people would accept the second part of the angel's greetings of 'good will.' We do not miss this will today" ${ }^{34}$.

An analytical look at the content of the recorded experiences and the texts of the prayers themselves allow to see the structural elements of the authentic act of celebrating the Paschal mystery, a source of hope and vital force. The elements of the celebration of the liturgy, especially the Eucharist, in the dimension of the de-realization of the world and the de-humanization of the human being, constituted the implementation - by virtue of Christ - irreplaceable spiritual values. By virtue of these values the man in the labor camps was able to free himself from the existence purposely reduced to biologism, turpism and nihilism. Liberation was inspired with the spirit of the Passover of Christ. However, it should be remembered that not only the aesthetic dimension was significant here, but a concrete ethical foundation - the discovery of a new dimension of humanity in Christ free from fear and hatred ${ }^{35}$. Through the experience of the liturgy, the man in the camps - through absolute and unconditional trust in God - tried to trust in humanity represented by himself.

34 S. Czapiewski, Przez zakratowane okienka. Wspomnienia syberyjskie (dokończenie), "Przegląd Powszechny" 106:1989 no. 12 p. 388. See also the poem of Z. Broncel: "Christ came down to hell, the hand of the priest and the Word of the Savior of the heavens is chasing him and in his hands the body and blood of the Lord - Kyrie and Gloria, the Gospel and Sanctus, Elevation and Holy Communion... The holy wafer visited the secondary catacombs. (...) "Holy God" - these words - in a subdued way - hover in the sky, Trust in God proclaim, ask for perseverance, pity, for salvation, Faith stops the rivers, mountains from the places it moves, It will ask for strength, freedom, family unity, return to homes. Because your will is born of your faith, by the will of yours a miracle will be born. And what today is considered a delusional dream turns into a deed of life." Z. Broncel, Msza święta w baraku, in: Z teki, op. cit., 16.

35 Cf. W. Hryniewicz, Nasza Pascha z Chrystusem, Lublin 1987, 374. 